\title{
Push and Pull Motivations on Halal Tourism
}

\author{
Faulina, Efni Siregar*, Vivianti Novita, Siti Arimbi \\ Department of Business Administration, Politeknik Negeri Medan, Indonesia
}

\begin{abstract}
The purpose of this study was to examine empirically the causal relationships among push and pull travel motivations, destination image, and tourists' travel satisfaction on halal tourism. The research conceptual framework and hypotheses were constructed, based on previous theoretical and empirical studies. A questionnaire survey was conducted with 200 respondents to collect the primary data. Multiple regression and Path Analyses were conducted to test the research hypotheses. As a result, push and pull factors had directly positive influences on tourist's travel satisfaction. Besides, the results also showed that push and pull factors were slightly indirect effect tourist's travel satisfaction through the halal destination image. Consequently, local government and business organizations working in the tourism sector should pay attention to the essential roles of push and pull factors. To attract more potential visitors and improve their satisfaction, enhance their perceived on halal destination image by doing the facility improvement and marketing activities are the compulsory actions.
\end{abstract}

Keywords: destination image, halal tourism, motivation, push and pull, travel satisfaction.

\section{INTRODUCTION}

Halal tourism becomes one of the fastergrowing sectors of the global travel industry [1]. No alcohol, no pork, separate swimming pools for men and women, prayer facilities, and the other provisions based on the Muslim belief in the tourism facilities and services are needed in halal tourism. The performance of halal tourism began to rise in Muslim and non-Muslim countries. Although the concept of Halal tourism exclusively designed by Muslim roles, it inclusively covers the services for all, including non-Muslim travelers. In addition to the good servicing practices, the core of halal tourism emphasizes the principles of shariah-compliant aspects in both tourism management and services [2].

In 2018, there were 140 million international Muslim travelers, according to the latest Global Muslim Travel Index for Mastercard and Crescent Rating. By 2026, the segment is predicted to grow to 230 million people, forecasted $\$ 300$ billion into the global economy [3]. This huge number of tourists need information, of course, about halal services and facilities at destinations to simplify their journeys.

Despite having five official religions and hundreds of ethnic groups, Indonesia has the largest Muslim population in the world that contributes $12.7 \%$ of the world's Muslims. According to a report, approximately 222 million people, or $87 \%$ of its population are Muslims [4].

\footnotetext{
* Correspondence address:

Efni Siregar

E-mail : efnisiregar@polmed.ac.id

Address : alan Almamater No. 1, Kampus USU Padang Bulan, Medan - 20155
}

In Indonesia, the tourism sector as one of the primary income sources for GDP (Gross Domestic Product). Therefore, understanding of Halal tourism concept and apply it in the Indonesian Tourism sector is expected to increase the national income. Knowing the needs of domestic and international tourists in Halal tourism is an urgent matter to recognize the tourists' concept of halal tourism. The study about motivations and destination image and tourist travel satisfaction is the obligatory process to understand tourists' needs and satisfaction in halal tourism.

\section{Halal Tourism}

Halal tourism is an umbrella term for tourism activities and products, includes Halal food, Halal Airlines, and Halal or Shariah-compliant Hotels [5]. It has economic, socio-cultural and religious aims as the revival of Islamic cultures and the spread of Islamic values, the economic benefit for Islamic societies, the strengthening of Islam self-confidence stereotyping in comparison to other cultures and lifestyles [6]. The definition focuses on Islamic law and its requirements to meet the tourist needs but ignored the religion of tourists (Muslims) and other dimensions [7].

Halal tourism is one of the new phenomena that emerged from the growth of the Halal industry. As Halal matters advancing the tourism industry, many Muslim and non-Muslim countries are set to capture the Muslim tourists' market by providing tourism products, facilities, and infrastructures to cater to their needs [8].

\section{Travel Motivation}

Travel motivation is the fundamental reason for the traveling behaviour and plays a vital role 
in understanding the decision-making process of tourists [9]. It has drawn increasing attention from the travel industry and motivates Indonesian tourists to undertake Halal tourism activities during their stay. The push-pull theory has been widely applied to tourism research, and specifically to traveler motivations. The theory provides a framework for examining customers' motivations for choosing to visit specific locations by analyzing two aspects: factors that push customers into making decisions via internal forces and factors that pull customers to choose desired locations via external forces, such as the attributes of the destination [10].

Some common push factors found in many studies include situational factors [11], sociopsychological factors (escape from routine everyday life, relaxation, exploration, social interaction, relationship enhancement, prestige), novelty-seeking, cultural experience, and escape $[12,13]$. Pull factor characteristics refer to place as a tourism product that defines a destination: static factors (scenery, cities, climate, wildlife, historical, and local cultural attractions); dynamic factors (accommodation, food, entertainment, access, political condition, and trends in tourism); and information such as marketing and advertising $[13,14]$. Push and pull travel motivations are not independent, but related to each other, push factors to refer to individual and pull factors pull tourists to visit the destinations $[15,16]$. Tourist motivation not only exerts influence over the choice of destinations but also over satisfaction [17].

\section{Destination Image and Satisfaction}

Destination image defined as an expression of knowledge, impressions, prejudices, imagination, and emotion and individual has of a specific place. In terms of impressions, regarding the fact that they may be true or false, real or imagined [18]. The destination image formation acts as the influence of the image on tourist satisfaction. It is important to gain a better understanding of tourists' perceptions of destination image, why they are loyal to a destination, and why it drives loyalty. One of the key elements of destination marketing success is tourist satisfaction because it influences the choice of destination $[19,20]$. A significant relationship occurs between tourist involvements, place attachment, and satisfaction [21].

Tourists' travel satisfaction is the extent of overall pleasure or contentment felt by the visitor, resulting from the ability of the trip experience to fulfill the visitor's desires, expectations, and needs about the trip [20]. Tourist satisfaction is one of the prime variables to sustain competitive business in the tourism industry because it affects the choice of destination, consumption of products, and services [22]. The evaluation of tourist satisfaction is generally a direct measurement of its overall satisfaction with the destination experience; few studies involving satisfaction with destination attributes or combining a variety of common satisfaction models [17].

Various concepts explained the tourist's travel satisfaction in direct and indirect influences. Figure 1 illustrates the proposed hypothetical model in this study.

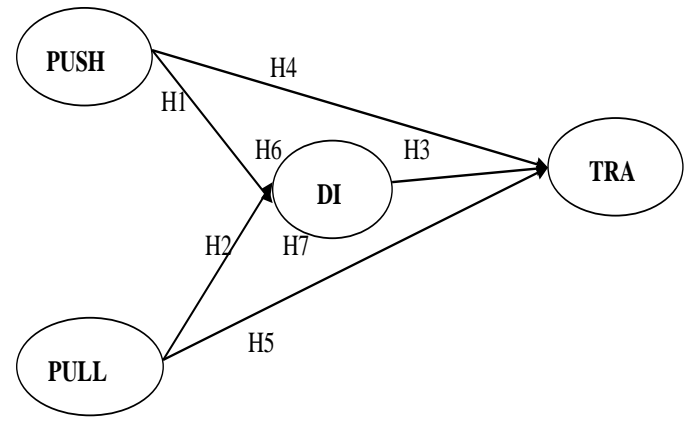

Figure 1. The Proposed Model

Description:

PUSH: Push factor, PULL: Pull factor, DI: destination image, TRA: tavel satisfaction.

$\mathrm{H} 1$ :Push factor is positively and directly affect halal destination image

H2 :Pull factor is positively and directly affect halal destination image

H3 :Halal destination image is positively and directly affect tourists' travel satisfaction.

H4 :Push factor is positively and directly affect halal destination image

H5 :Pull factor is positively and directly affect tourists' travel satisfaction

H6 :Push factor indirectly affects tourists' travel satisfaction through halal destination image

H7 :Pull factor indirectly affects tourists' satisfaction through tourists' destination image

\section{MATERIAL AND METHOD}

A structured interview utilized to gather basic information about Indonesian tourists from Medan. This instrument provides primary pertinent information to develop the questionnaire survey. The survey questionnaire was used as the main data gathering instrument for this study based on structured interviews and previous literature. After the development of the survey questionnaire, the pilot test was conducted with a validity and reliability study to examine the construct of the questionnaire. 
The items of the questionnaire were based on literature reviews. The questions were in the form of five-scale Likert statements from 'strongly disagree' to 'strongly agree'. The instrument of the study was developed based on the review of related literature on Push and Pull motivation factors, destination image, and travel satisfaction. About twenty-four Likert scale questions in the questionnaire to help this study to get an overview of the research question divided into three categories: push and pull motivation, destination image, and travel satisfaction

\section{Data Collection}

This study will use descriptive and causal research design and mainly applied a quantitative approach to examine the effects between variables. The descriptive method was used to describe the profile of Indonesian tourists in Medan city, collecting data through a questionnaire to answer the question concerning the motivation factors and travel satisfaction. The survey was delivered and collected online through Google form and offline and conducted from October to November 2019.

The questionnaire distributed to Indonesian Muslim tourists who stay in Medan and wish to travel for Halal tourism purposes. One of the reasons Medan is selected because it has international airports that offered international flights to different countries. This study used purposive sampling with total respondents was 200 people of Medan.

Table 1. Socio-demographic profile of therespondents

\begin{tabular}{|c|c|c|c|}
\hline \multicolumn{2}{|c|}{ Socio-Demographic } & \multirow{2}{*}{$\begin{array}{c}\text { Frequency } \\
49\end{array}$} & \multirow{2}{*}{$\begin{array}{c}\% \\
24.7 \%\end{array}$} \\
\hline & Male & & \\
\hline Gender & Female & 151 & $75.3 \%$ \\
\hline \multirow{4}{*}{ Age } & $10-15$ & 0 & $0 \%$ \\
\hline & $16-21$ & 102 & $51.1 \%$ \\
\hline & $22-27$ & 63 & $31.7 \%$ \\
\hline & $\geq 28$ & 34 & $17.2 \%$ \\
\hline \multirow{4}{*}{$\begin{array}{l}\text { Education } \\
\text { Level }\end{array}$} & Junior High School & 0 & $0 \%$ \\
\hline & High School & 9 & $45.9 \%$ \\
\hline & Diploma & 46 & $23.2 \%$ \\
\hline & Bachelor Degree & 62 & 138 \\
\hline \multirow{4}{*}{$\begin{array}{l}\text { Number of } \\
\text { Visit }\end{array}$} & One time & 6 & $3.2 \%$ \\
\hline & Two times & 6 & $3.2 \%$ \\
\hline & Three times & 4 & $1.6 \%$ \\
\hline & $\geq 4$ times & 184 & $91.9 \%$ \\
\hline
\end{tabular}

As shown in the Table 1, the distribution according to the gender of respondents showed that $\mathbf{2 4 . 7} \%$ were males and $\mathbf{7 5 . 3} \%$ females. More than half of respondents (51.1\%) were 16-21 years old, $31.7 \%$ were $22-27$ years old, and $17.2 \%$ of respondents had 28 years and above.
The results of 200 respondents' recent education indicated that $45.9 \%$ of them were in high school, $30.8 \%$ were bachelor's degrees, and $23.2 \%$ of respondents were students in diploma. By analyzing the number of visits as a tourist, it was determined that most respondents had traveled as tourists to different destinations more than four times (91.9\%).Data received from the survey were processed by using the IBM SPSS (Statistical Package for the Social Sciences) statistical software version 22.0 to analyze the data. The reliability test used to ensure the indicators were reliable. To achieve scale stability, Exploratory Factor Analysis (EFA) was used for scale development and to identify underlying constructs. For this study, two exploratory factor analyses (EFA) conducted with Kaiser-MeyerOlkin and Bartlett's test of sphericity and Varimax rotation. The KMO measure of sampling adequacy for both groups of independent $(\mathrm{KMO}=0.711)$ and dependent variables ( $\mathrm{KMO}=0.500)$ was greater than the minimum value for a good factor analysis 0.50 [23]. Also, Bartlett's test of sphericity was significant (Sig.=.000), indicating the sufficient correlation between the variables.

Almost all the factor loadings meet the minimum requirement except for several independent variables: 'Halal destination is known as the clean place' (0.484), 'I prefer to visit destinations which have many tourists' attractions' (0.481), I like to visit historical tourist's destination' (0.451) and one dependent variable: 'I will be satisfied if the tourists' destination is safe ' $(0.358)$. The items that met the minimum requirement were included in further processes. Regression and Path Analysis conducted to identify the interrelationship among variables to confirm the research hypotheses. Subsequently, Multiple Regression and Path Analysis were used to explore the causal relationships among variables and then conclude in the research hypotheses.

\section{Descriptive statistics of the constructs}

Refer to Table 2, items concerning Push Factors such as 'psychological factors' (PSY1), 'static factors' (STAT1), and 'dynamic factors' (DYN3) were among the highest mean values $(4.55 \pm 0.646,4.60 \pm 0.656,4.34 \pm 0.872$, respectively). The results suggested the importance of many halal destinations offered to explore with natural and cultural attractions, and the respondents were looking forward to having halal facilities while traveling $(4.22 \pm 0.957)$. 
At the EFA stage, items with a loading factor of \pm 0.5 retained and grouped into factors. Besides, Bartlett's test of sphericity was significant (Sig.=.000), indicating the sufficient correlation between the variables. As shown in Table 2, one push motivation factors (SIT3) and two pull motivation factors (STAT2 and STAT3) pulled out of the sample set. Dependent variables, which were Destination Image (DI) and tourists' Travel Satisfaction (TSA), have four and six items. A congeneric factor with two items can be considered as the factor that has a significant relationship with any other factor [24]. All of the totals of 25 items retained, respectively.

Table 3 presents the items about Destination Image and tourists' travel satisfaction. DI2, DI4, and all the TSA items were among the highest mean values, except TSA5 (0.538 \pm 0.358$)$. Prayer place, halal facilities in accommodations, and friendly societies are the important factors in destination image and tourists' travel satisfaction.

Table 2. Mean scores, Standard Deviation, EFA, and Reliability of Push and Pull Motivators

\begin{tabular}{|c|c|c|c|c|c|}
\hline & & Mean & Std Deviation & Factor Loading & Cronbach $\alpha$ \\
\hline \multicolumn{6}{|c|}{ Push Motivation Factors } \\
\hline SIT1 & Want to visit halal destination & 4.00 & 1.065 & 0.656 & \\
\hline SIT2 & The halal destination is known as the safest place & 4.08 & 0.958 & 0.632 & 0.845 \\
\hline SIT3 & The halal destination is known as the clean place & 3.85 & 0.982 & 0.484 & \\
\hline PSY1 & I like to travel to new places & 4.55 & 0.646 & 0.517 & \\
\hline PSY2 & I like to meet new people & 4.06 & 0.937 & 0.598 & \\
\hline PSY3 & I love to explore the new cultural experimental & 4.12 & 0.838 & 0.659 & 0.620 \\
\hline PSY4 & I always want to travel to halal destinations & 3.84 & 1.202 & 0.713 & \\
\hline PSY5 & I believe halal tourism keeping me feel comfortable & 4.01 & 1.032 & 0.715 & \\
\hline \multicolumn{6}{|c|}{ Pull Motivation Factors } \\
\hline STAT1 & I prefer to visit the beautiful natural attractions & 4.60 & 0.656 & 0.634 & \\
\hline STAT2 & $\begin{array}{l}\text { I prefer to visit destinations which have many tourists' } \\
\text { attractions }\end{array}$ & 3.82 & 0.843 & 0.481 & 0.503 \\
\hline STAT3 & I like to visit historical tourist's destination & 4.01 & 0.889 & 0.451 & \\
\hline DYN1 & I prefer to visit destinations that offer halal facilities & 4.22 & 0.957 & 0.569 & \\
\hline DYN2 & $\begin{array}{l}\text { Halal food is the main reason to visit the tourist's } \\
\text { destination }\end{array}$ & 4.20 & 0.975 & 0.698 & \\
\hline DYN3 & $\begin{array}{l}\text { I want to visit destinations if offer many prayers } \\
\text { places }\end{array}$ & 4.34 & 0.872 & 0.584 & 0.777 \\
\hline DYN4 & $\begin{array}{l}\text { I want to visit a halal destination because of friends } \\
\text { and relatives }\end{array}$ & 3.97 & 0.805 & 0.566 & \\
\hline INF1 & $\begin{array}{l}\text { Magazines and newspapers wrote many interesting } \\
\text { halal destinations }\end{array}$ & 3.76 & 0.942 & 0.703 & \\
\hline INF2 & $\begin{array}{l}\text { I want to visit a halal destination because of social } \\
\text { media reviews }\end{array}$ & 3.83 & 0.950 & 0.750 & 0.868 \\
\hline INF3 & $\begin{array}{l}\text { I want to visit halal tourism because of the travel } \\
\text { agent's promotions }\end{array}$ & 3.66 & 1.039 & 0.682 & \\
\hline
\end{tabular}

Table 3. Mean scores, Standard Deviation, EFA, and Reliability of Destination image and Satisfaction factors

\begin{tabular}{|c|c|c|c|c|c|}
\hline \multicolumn{2}{|c|}{ Construct } & Mean & Std Deviation & Factor Loading & Cronbach $\alpha$ \\
\hline \multicolumn{6}{|c|}{ Perceived Destination Image } \\
\hline DI1 & My concern is halal facilities & 4.18 & 0.795 & 0.577 & \multirow{4}{*}{0.807} \\
\hline DI2 & Fast and easy access to the prayer place & 4.34 & 0.764 & 0.713 & \\
\hline DI3 & $\begin{array}{l}\text { The security concern in halal destinations is my } \\
\text { purpose }\end{array}$ & 4.48 & 0.720 & 0.545 & \\
\hline DI4 & Review and news lead me to halal destinations & 4.20 & 0.786 & 0.616 & \\
\hline \multicolumn{6}{|c|}{ Satisfaction } \\
\hline TSA1 & $\begin{array}{l}\text { The access to the halal destination is easy and } \\
\text { reachable }\end{array}$ & 4.44 & 0.711 & 0.659 & \multirow{6}{*}{0.877} \\
\hline TSA2 & $\begin{array}{l}\text { I will be satisfied if the halal facilities offered by the } \\
\text { accommodations }\end{array}$ & 4.39 & 0.739 & 0.734 & \\
\hline TSA3 & $\begin{array}{l}\text { I will be satisfied if many restaurants around the halal } \\
\text { destinations }\end{array}$ & 4.41 & 0.762 & 0.670 & \\
\hline TSA4 & $\begin{array}{l}\text { I will be satisfied if the affordable price for halal } \\
\text { tourism offered }\end{array}$ & 4.62 & 0.629 & 0.574 & \\
\hline TSA5 & I will be satisfied if the tourists' destination is safe & 4.72 & 0.538 & 0.358 & \\
\hline TSA6 & $\begin{array}{l}\text { I will be satisfied if the people in the halal destination } \\
\text { are tourists' friendly }\end{array}$ & 4.48 & 0.760 & 0.722 & \\
\hline
\end{tabular}




\section{RESULT AND DISCUSSION}

Pearson's Correlation Analysis and Linear Regression Analysis were applied to find out the relationship among variables. Table 4 illustrates the positive correlations between Push and Pull as independent variables, the mediate variable (Destination Image), and the dependent variable (tourists' Travel Satisfaction). This means that the stronger Push and Pull travel motivations the travellers had, the higher the Destination Image and Travel Satisfaction degree.

\begin{tabular}{|c|c|c|c|c|}
\hline \multicolumn{2}{|c|}{ TSA } & \multirow[t]{2}{*}{1} & \multirow[t]{2}{*}{2} & \multirow[t]{2}{*}{3} \\
\hline 1. PUSH & 0.492 & & & \\
\hline 2. PULL & 0.570 & 0.584 & & \\
\hline 3. DI & 0.692 & 0.610 & 0.744 & \\
\hline Mean & 27.06 & 36.72 & 40.79 & 17.20 \\
\hline S.D. & 3.278 & 4.461 & 5.196 & 2.440 \\
\hline
\end{tabular}

Notes: PUSH: Push factor, PULL: Pull factor, DI: destination image, TSA: tavel satisfaction.

H1: Push factor is positively and directly affect halal destination image

H2: Pull factor is positively and directly affect halal destination image

The result of the data revealed that there were significant positive relationships between the mediate variable of $\mathrm{DI}$ and the independent variables: Push $(r=0.610, p<0.01)$ and Pull $(r=0.744 . p<0.01)$. Regression Coefficient of Push and Pull were $\beta=0.146, p=.000$ and $\beta=0.276$, $p=.000$, respectively. It implied that Push and Pull factors had positive and relatively strong effects on Destination Image. Furthermore, Push and Pull factors could explain $60 \%$ of the variation of tourist Destination Image $\left(R^{2}=0.600\right)$.

H3: Halal destination image is positively and directly affect tourists' travel satisfaction.

There was a positive correlation between the mediate variable (DI) and the dependent variable (TSA) with $r=0.692, p<0.001$. The coefficient of determination $(\beta=0.929, p=.000)$ indicated the strong influence of Destination Image on Travel satisfaction at the $99 \%$ confidence level. The $\mathrm{R}$ squared value was 0.478 , which means $47.8 \%$ of the variation of Travel Satisfaction can be explained by halal Destination Image.

H4: Push factor is positively and directly affect halal destination image

H5: Pull factor is positively and directly affect tourists' travel satisfaction
The Pearson Correlation analysis results showed the positive correlations between two independent variables and the dependent variable (TSA), with $r=0.492, p<0.01$, and $r=0.570, p<0.01$, respectively. Travel Satisfaction directly affected by the Push factor $(\beta=0.177$, $p=.001)$ and Pull factor $(\beta=0.270, p=.000)$ in a positive direction. The $R^{2}=0.363$ implied that the Push and Pull factors can explain $36.3 \%$ of the variation of tourists' Travel Satisfaction on halal destination.

H6: Push factor is indirectly affect tourists' travel satisfaction through halal destination image

H7: Pull factor indirectly affect tourists' satisfaction through tourists' destination image

The two independent factors directly influenced DI, and then this mediate variable caused an effect on Travel Satisfaction with $\beta=0.929, p=0.000$. Consequently, Push and Pull factors create indirect effects on Travel Satisfaction. Sobel Test was used to access the significance of the indirect effects [25]. It can be concluded from this test that the indirect effects of Push and Pull on TRA were indeed significantly different from zero at $p<0.05$ (two-tailed) and the mediation of $D I$ in this study was true with the residual coefficients were 0.632 (Push $\rightarrow$ DI) and 0.647 (Push and Pull $\rightarrow$ DI $\rightarrow$ TSA).

Table 5 summarized the causal effect of independent variables and mediate variable on Travel Satisfaction. As regards the total effects that were shown, $D I$ had the strongest impact on TSA ( $\beta=0.564)$, followed by Pull motivation factor $(\beta=0.332)$. Push factor had the slightest effect on TSA to halal destination with $\beta=0.151$ only. The total effect of these factors on TSA was 1.047, in which direct effects of factors of Push, Pull, and DI accounted for more than $60 \%$ while indirect effects made up nearly $40 \%$.

Table 5. Regression and Sobel Test Summary

\begin{tabular}{lcccl}
\hline Variable & $b$ & $\beta$ & $\begin{array}{c}\text { Std } \\
\text { Error }\end{array}$ & Sig \\
\hline Push $\rightarrow$ DI & 0.267 & 0.146 & 0.030 & 0.00 \\
Pull $\rightarrow$ DI & 0.588 & 0.276 & 0.026 & 0.00 \\
Push $\rightarrow$ TSA & 0.241 & 0.177 & 0.051 & 0.00 \\
Pull $\rightarrow$ TSA & 0.429 & 0.270 & 0.044 & 0.00 \\
DI $\rightarrow$ TSA & 0.564 & 0.757 & 0.107 & 0.00 \\
Push $\rightarrow$ DI $\rightarrow$ TSA & 0.151 & 0.067 & 0.091 & 0.00 (Sobel) \\
Pull $\rightarrow$ DI $\rightarrow$ TSA & 0.332 & 0.061 & 0.097 & 0.00 (Sobel) \\
\hline
\end{tabular}

The empirical results of this study supported the model, which provided a conceptual framework to positively explain and predict the items that provide tourists' satisfaction while 
traveling to halal destinations. The statistical findings showed that Push and Pull factors did not only directly affect tourists' Travel Satisfaction, but also had indirect impacts on travel satisfaction through Destination Image. It means that when travelers have stronger intrinsic desires to go on a vacation and perception towards the halal features, attractions, or attributes of a destination, they may get the positive Perceived Destination Image as well as satisfaction while traveling.

This study proved that Muslim tourists always want to travel to a halal destination because it will comfort them. They prefer halal food nearby tourist attraction and reachable prayer places near the tourists' attractions because the Muslim tourists can practice their act of religious devotion while visit tourists' destinations. The support of accommodation' managers to facilitate and to serve the halal facilities and services is one of the biggest favours, too [8]. The clean and safe places while visiting tourists' destinations, surprisingly were not the main subjects of this study.

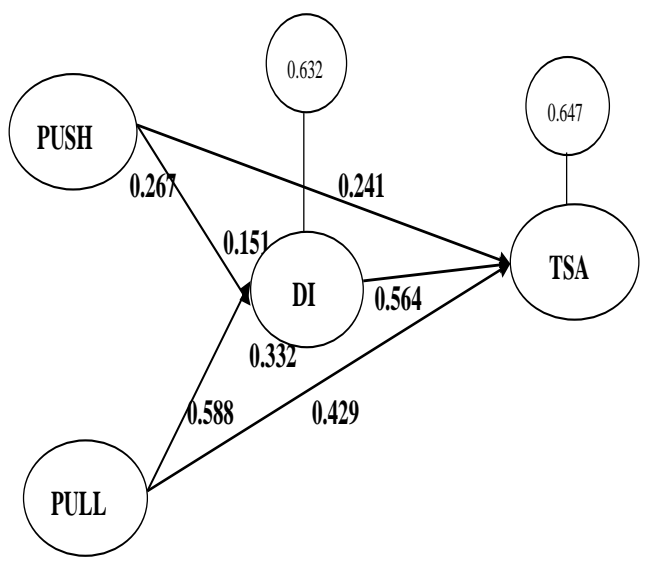

Figure 2. Path Diagram

This finding was supported by some previous researches that agreed that travel motivation, including situational and psychological motives (Push factor) and external motives of the destination attribute (Pull factor), positively affected tourists' travel satisfaction of destination [26,27]. The results in this research indicate that Push and Pull factors had a slight influence on tourists' travel satisfaction in the halal destination.

It was concluded that Push and Pull factors had significant effects on the destination image. Therefore, the halal destination image handles the important role to satisfy tourists while traveling to halal destinations. It means the halal destination depends on the image created. The tourists' satisfaction or dissatisfaction is much dependent on how well the tourists perceived about the halal concept and the destination image.

\section{Recommendation}

The findings of this research proposed some constructive recommendations for business organizations working in the tourism sector, destination marketers, and local governments. First, based on the empirical research findings, this study provided practical evidence on the causal relationships between travel motivation, destination image, and satisfaction to visit halal destination; to increase the awareness of tourism government and organizations about the role of push and pull factors and their positive influences on destination image and tourist's travel satisfaction. They should pay attention to both intrinsic and extrinsic reasons why people decide to travel to the halal destination, and their basic needs and expectations about that trip as well (halal food, no alcohol drink, prayer places, etc) to comfort them while traveling.

Moreover, building the image as a halal destination is compulsory to attract more tourists from Muslim countries such as Indonesia, Malaysia, and Middle East Countries. The image can be build by preparing the Muslim's basic needs, in minimum, and then share this improvement through social media, reviews on magazines and newspapers, television, and online promotion, respectively. Besides, the local governments should consider protecting the tourists by developing the policies and to educate the societies to respect and help the tourists while traveling to their places, with no exception. Destination marketers can design marketing strategies that show the uniqueness of nature and cultures as well as the affordable facilities and services prepared for Muslims. The city which promotes halal tourism should be aware of the Muslim requirements in the halal concept.

\section{CONCLUSION}

This study aimed to identify the travel motivation of Muslim travelers and investigate the causal relationships among the push and pull travel motivations, destination image, and tourists' travel satisfaction. Based on previous theoretical and empirical studies, the research conceptual framework and hypotheses were constructed.

After analyzing the collected data, all proposed hypotheses and models were accepted, 
and the research's goals have successfully obtained. Both push and pull motivation factors have a significant and positive influence on halal destination image, but only have a slight effect on tourists' travel satisfaction. Therefore, business organizations working in the tourism sector should take serious attention to the essential roles of push and pull factors, to understand and respond to tourists' demands and expectations when they travel to destinations. The results of this research can be used as valuable and accurate information for destination governments, marketers, and managers to implement policies, strategies, and plans to attract more potential Muslim visitors and to improve their travel satisfaction and encourage them to visit and re-visit the destination.

\section{REFERENCES}

[1] Kamin, D. 2019. The rise of halal tourism. Available at: https://www.nytimes.com/ 2019/01/18/travel/the-rise-of-halaltourism.html.

[2] Jaelani, A. 2017. Halal tourism industry in Indonesia: Potential and prospects. International Review of Management and Marketing 7(3). 25-34.

[3] Neubauer, I. L. 2019. Halal tourism boom draws Muslim holidaymakers to Asia. Available at: https://asia.nikkei.com/ Business/Business-trends/Halal-tourismboom-draws-Muslim-holidaymakers-toAsia2.

[4] Lipka, M. 2017. Muslim and Islam: Key findings in the U.S. and around the world. Available at: http://www.pewresearch.org/ fact-tank/2017/02/27/muslims-and-islamkey-findings-in-the-u-s-and-around-theworld/.

[5] Mansouri, S. 2014. Role of halal tourism ideology in destination competitiveness: A study on selected hotels in Bangkok, Thailand. Proceeding International Conference on Law, Education, and Humanities (ICLEH'14). 20-23.

[6] Al-Hamarneh, A., and C. Steiner. 2004. Islamic tourism: Rethinking the strategies of tourism development in the Arab World after September 11, 2001. Comparative Studies of South Asia, Africa and the Middle East 24(1). 173-182.

[7] Battour, M. 2018. Muslim travel behavior in halal tourism. Mobilities, Tourism and
Travel Behavior - Contexts and Boundaries, 3-16.

[8] Samori, Z., N. Z. Md Salleh, and M. M. Khalid. 2016. Current trends on Halal tourism: Cases in selected Asian countries. Tourism Management Perspectives 19, 131136.

[9] Wall, G., and A. Mathieson. 2006. Tourism: change, impacts, and opportunities. Pearson Education Limited. Harlow.

[10] Crompton, J. L. 1979. Motivations for pleasure vacation. Annals of Tourism Research 6, 408-424.

[11] Misbah, H. 2014. Customer switching behavior: An exploratory study of predictive factors in the UK retail banking context. Dissertation. University of Edinburg, UK.

[12] Jensen, J. M. 2011. The relationships between socio-demographic variables, travel motivations and subsequent choice of vacation. Proceeding of International Conference on Economics, Business and Management, IPEDR, Vol. 22. IACSIT Press. Singapore.

[13] Dayour, F., and C. A. Adongo. 2015. Why they go there: International tourists' motivations and revisit intention to Northern Ghana.Tourism Management 4(1), 7-17.

[14] Madden, K., B. Rashid, and N. A. Zainol. 2017. Determinants of Intention to Visit Phuket. Thailand. Journal of Tourism and Management Research 2(1), 31-43.

[15] Kim, K. 2008. Analysis of the structural equation model for the student pleasure travel market: motivation, involvement, satisfaction, and destination loyalty. Journal of Travel \& Tourism Marketing 24(4), 297313.

[16] Khuong, M. N., and T. T. Ha. 2014. The influences of push and pull factors on the international leisure tourists' return intention to Ho Chi Minh City, Vietnam - a mediation analysis of destination satisfaction. International Journal of Trade, Economics and Finance 5(6), 490-496.

[17] Li, Z., A. Rehman, B. Zhao, and Z. Peng. 2016. Analysis of the relationship between tourist motivation, satisfaction and loyalty for China special theme tourism. Asian Research Journal of Arts and Social Sciences 1(5), 1-14.

[18] Ruiz, E. C., G. B. Gonzales, and D. T. Zamora. 2018. Destination image, satisfaction and destination loyalty in cruise tourism: the 
case of Malaga (Spain). Tourism and Management Studies 14(1), 58-68.

[19] Yoon, Y., and M. Uysal. 2005. An examination of the effects of motivation and satisfaction on destination loyalty: A structural model. Tourism Management 26(1), 45-56.

[20] Chen, C. F., and D. Tsai. 2007. How destination image and evaluative factors affect behavioural intentions?. Tourism Management 28, 1115-1122.

[21] Hwang, S. N., C. Lee, and H. J. Chen. 2005. The relationship among tourists' involvement, place attachment and interpretation satisfaction in Taiwan's National Parks. Tourism Management 26(2), 143-156.

[22] Kozak, M., and M. Rimmington. 2000. Tourist satisfaction with Mallorca, Spain, as an off-season holiday destination. Journal of Travel Research 38(3), 260-269.

[23] Field, A. 2000. Discovering statistics using SPSS for Windows. Thousand Oaks - New Delhi: Sage publications. London.

[24] Hair, J. F., W. C. Black, B. J. Babin, R. E. Anderson, and R. L. Tatham. 2010. Multivariate data analysis. Pearson Education. New Jersey.

[25] Kline, R. B. 2011. Principles and practice of Structural Equation Modeling. Guilford Press. New York.

[26] Pratminingsih, S. A., C. L. Rudatin, and T. Rimenta. 2014. Roles of motivation and destination image in predicting tourist revisit intention: A case of Bandung Indonesia. International Journal of Innovation, Management, and Technology 5(1), 19-24.

[27] Khuong, M. N., and P. A. Nguyen. 2017. Factors affecting tourist destination satisfaction and return intention. A study in Ho Chi Minh City, Vietnam. Journal of Economics, Bussiness and Management 6(2), 95-102. 